\title{
The Influence of Origami and Rectangular Crash Box Variations on MPV Bumper with Offset Frontal Test Examination toward Deformability
}

\author{
Imam Kusyairi ${ }^{1}$ \\ ${ }^{1}$ Politeknik Kota Malang \\ e-mail: kusyairi1408@gmail.com ${ }^{1}$
}

\begin{abstract}
Crash Box attached between bumper and chassis of a car serving as a kinetic energy absorber during the collision. In previous research, origami pattern crash box was tested at low speed, high speed, and frontal impact and oblique impact directions. They resulted predictable collapse and stable deformation patterns. It is directly proportional to the energy absorption during the impact. Origami pattern crash box was modeled in square but it cannot be used if it is applied in MPV car, the geometry is unsuitable to the bumper and chassis. Therefore, in this research, the crash box designed according to the size of bumper and chassis of MPV car where its shape is rectangular on the surface. This research will compare the deformation pattern between origami and rectangular crash box adapted to conditions and dimensions of the MPV car. Design built using CAD software and simulation is performed using FEM (Finite Element Method) software. Simulation test modeled with impactor, bumper and crash box, while offset frontal test with $16 \mathrm{~km} / \mathrm{h}$ impact speed conducted using material bilinear isotropic hardening modeling. Result show that origami pattern crash box has predictable deformation pattern than rectangular pattern crash box.
\end{abstract}

Keywords: crash box; origami; MPV Car; deformation

\section{INTRODUCTION}

Mortality due to accident is the third largest killer in the world. It triggers several parties to reduce the number of death in accident. In automotive, safety devices on automobile innovated to decrease injury, one of it is crash box. Crash box is tubular device placed between bumper and chassis. Widthly researches conducted to design crash box. There are two considerations in designing automotive structure to avoid kinetic energy on accident; kinetic energy absorption and force for retaining structure to accident. The two basic mode energy absorptions on automobile known for crash box which is able to restrain axial collapse and bending. Folds regularity or collapse depends on thickness ratio and geometry stiffness of curvature. The bigger curvature (bigger geometry stiffness), the regularity of folds pattern (collapse) [1]

Analysis by Ohokubu et al, Johnson et al, Wierzbicki and Akerstrom, Alexander et al, [1] initiated by mechanism prototype and kinematic of folds process and derivate from desirable destructive characteristics in simple correlation expressed by geometry and material characteristics. Assumptions in simplicity built to accommodate problems, such as inextension pure assumption (center/neutral surface is not stretched or shrank) of deformation mode for square column or extension deformation mode especially for tubular symmetrical column. This assumption restricted predictive capability of formulation. Latest work by Wierzbicki and Abramowicz incorporating approaches using plasticity kinematics. Average of collision load can be expressed in:

$$
P_{m}=38,27 M_{o} C^{1 / 3} t^{-1 / 3}
$$


Where $P_{m}$ is strength average during collision. $M_{0}=\sigma_{0} t^{2} / 4, \sigma_{0}$ is average of tension $\left(\sigma_{0}=(0,9\right.$ to 0,95$\left.) \sigma_{u}\right)$. $\sigma_{u}$ is ultimate tensile strength of material, $C=1 / 2(b+d)$ where $b$ and $d$ is rectangular column and $t$ is wall thickness. For square tube, $C=d=b$, Equation 1 is simplified into:

$$
P_{m}=9,56 \sigma_{0} t^{5 / 3} b^{1 / 3}
$$

Additional dents on crash box surface aimed to decrease tension of collision (first buckling). Crash box should have stable characteristics, repeated deformation modus, light, inexpensive, and simple manufacture process. Design development is needed in geometry crash box to decrease buckling mode and to obtain symmetric collapse mode (folding mechanism) for bigger energy absorption. This research developed geometry design in origami crash box with dents characteristics as pre-folded that collapse mode can be predicted and stable.

Origami pre-folded had been analyzed by Ma $\mathrm{J}$ and You Z [2] in origami crash box with low speed. Result shown that pre-folded is able to cause predictable collapse which leads to $92,1 \%$ energy absorption increment. Further research by Kusyairi, et al [3] designed origami crash box with Taguchi method on high speed impact examination. It shown that origami crash box is able to result predictable collapse mode and the biggest absorption is on those with many segments and geometry thickness. Research on origami crash box of corner collision was also conducted by Bintarto et al [4] and Zhou et al [5], it obtained that origami pre-folded was resulting predictable collapse mode.

The development of origami crash box on additional trapezoid geometry conducted by Zhou et al [6], while development in origami with reconfigurable polygonal cross-sections was conducted by Filipov et al [7], and development in origami on axial crushing was conducted by Song et al [8]. In addition to research with software, research also conducted with manufacture method. It was conducted by Ma, Jiayao [9] with Stamping method. It is depicted in Figure 1.1. Research by Li, Sigi et al [10] shown that origami crash box can be conducted in manufacture.

Previous research on origami crash box prototyped in square. Yet, it is difficult to be applied on MPV in Indonesia because there is difference on bumper and chassis dimension. Therefore, this research build rectangular and origami crash box with customized size for MPV. This research aimed to know deformation pattern of each crash box when geometry adjusted to MPV.
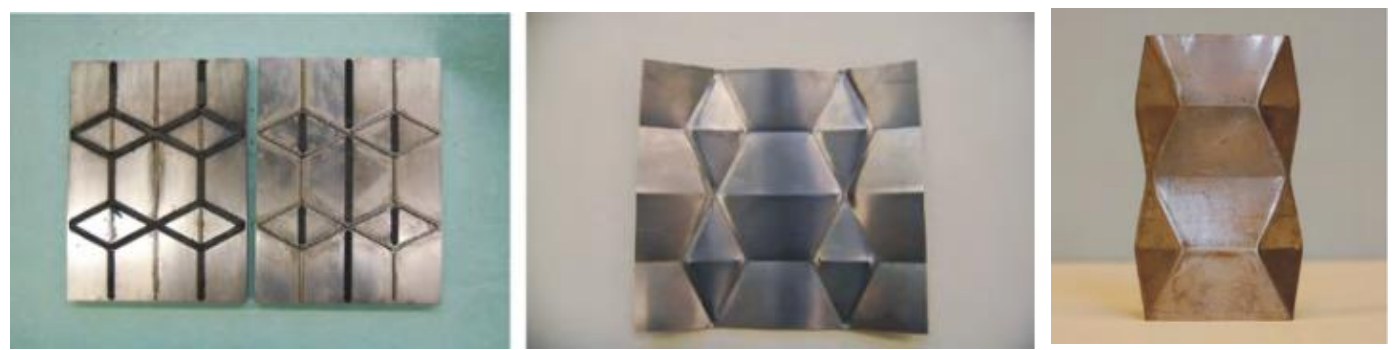

Figure 1.1 Building Origami Crash box with stamping method [9]

\section{Methodology \\ 2.1 Part Modelling}

Crash box modelling is adjusted to bumper and chassis size on MPV. This research used rectangular cross section as adjusted to MPV which is different to the previous research with square cross section. Bumper modeling depicted in Figure 2.1 placed in MPV body with $935 \mathrm{~mm}$ length and $150 \mathrm{~mm}$ width. Adjusted crash box customized with MPV chassis length and width also spot for nut and screw to ensure crash box and bumper in real condition. 
This research obtained crash box design with length and width as shown in Figure 2.2, $114 \mathrm{~mm}$ length $\times 58 \mathrm{~mm}$ width. This origami crash box has $120 \mathrm{~mm}$ height and 6 segments, it is based on the previous research [3], that it can absorb kinetic energy in maximum.

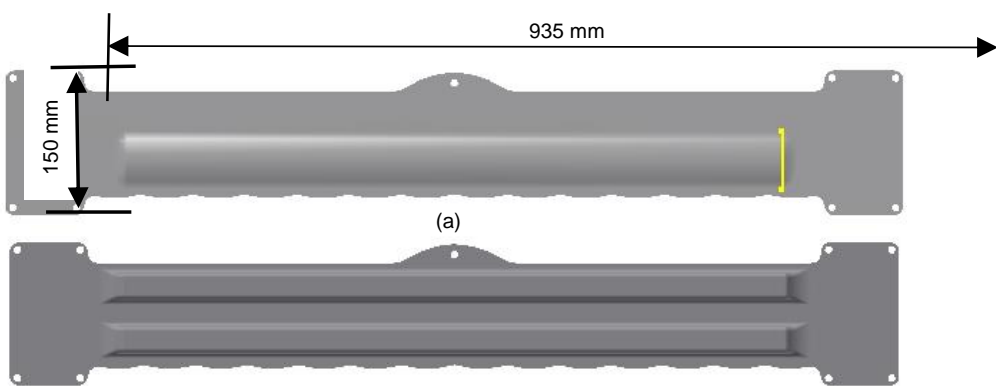

(b)

Figure 2.1 (a) Front-side Bumper and (b) Rear-side Bumper of MPV

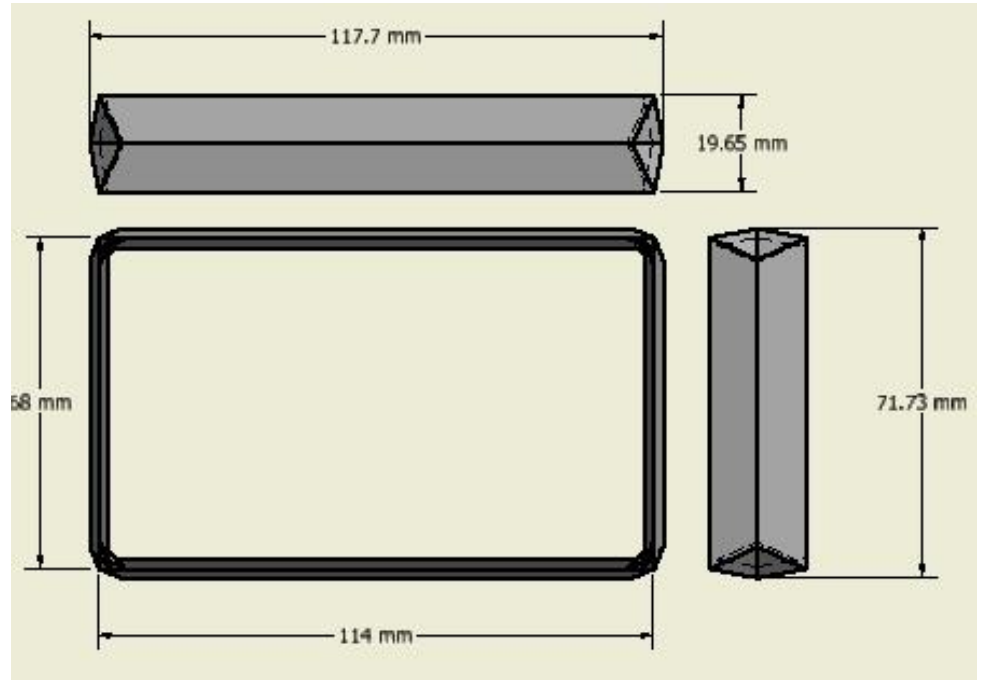

Figure 2.2 Crash box dimension

Figure 2.3 shows two crash boxes with the same dimension in length, width, and height. Differentiation between the two is pre-folded pattern on origami crash box. Assembly process after prototyping was conducted on bumper and chassis in crash box as regarded to be real condition. The result depicted in Figure 2.4 shows that bumper structure consists of bumper part 1 and 2, crash box and chassis. Plate thickness on crash box adjusted to bumper and chassis dimension in MPV.

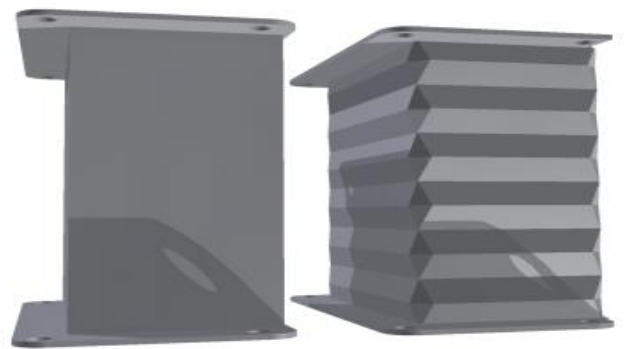

Figure 2.3 Prototype of crash box 


\subsection{Assembly}

Assembly for bumper can chassis structure illustrated in Figure 2.4. Crash box position between bumper and chassis means that during accident the crashed bumper transfer hit to crash box and if it cannot restrain impact load then the hit delivered to chassis. Considerations on crash box design in MPV is its location between bumper and chassis as MPV has short muzzle that between bumper and driver there is such distance.

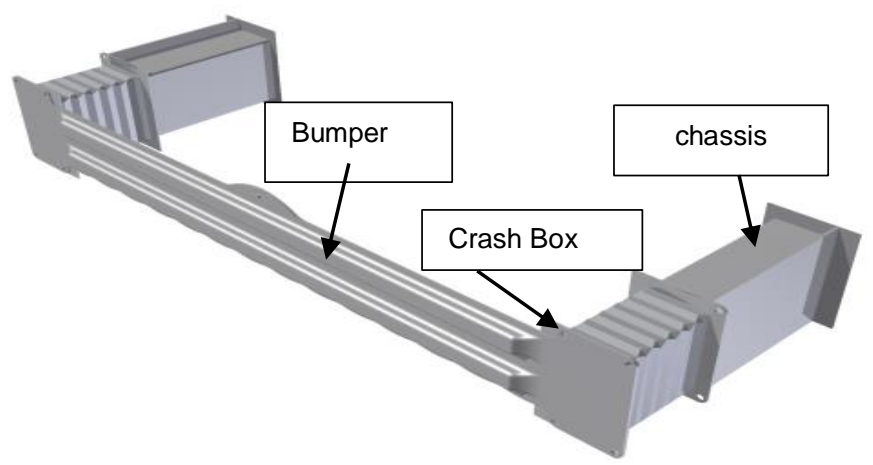

Figure 2.4 Crash box prototype on MPV bumper structure

\subsection{Examination}

After prototyping bumper structure with crash box, simulation conducted on Finite Element Software. Figure 2.5 illustrated meshing process on bumper structure and crash box. Meshing process is an important step in FEM simulation, it is dividing object volume analyzed into part or small cross sections. It means that if meshing process is smaller (fine) the result of FEM simulation is more accurate, which is it needs more time and bigger computation. In simulation process of testing bumper structure, impactor coincide with bumper in part 1 and 2 and furthermore, it pushed crash box. Impactor modeled as rigid body, while bumper and crash box as flexible. Fixed support is in the rear surface of crash box. Gravitation shown in Figure 2.6 A to y-axis direction. Impactor rate strike bumper structure in Figure 7 B to z-axis direction. Simulation process initiated by impactor moves to $z$ axis pushed bumper and bumper pushed crash box. Impactor moved in $16 \mathrm{~km} /$ hour by the target of $100 \mathrm{~mm}$ to $120 \mathrm{~mm}$ part hit the crash box. Impactor collision will cause bumper and crash box deformed. Simulation process depicted in Figure 2.6. Examination on bumper structure and crash box with Offset Frontal test is half of bumper structure hit by impact load.

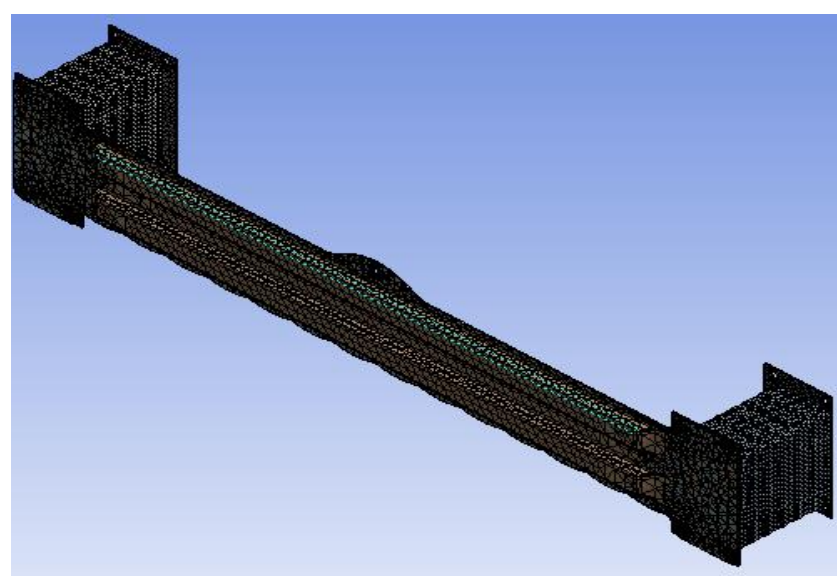

Figure 2.5 Meshing on bumper structure and crash box 
In this research the material is modeled as bilinear isotropic hardening where material sustain elastic deformation when impact occur continued with plastic deformation. When material had additional load, the material had deformation increment. Plasticity of material often be used in stretch analysis. Bilinear isotropic hardening model conducted by inserting yield strength data and modulus tangent on Finite Element Software.

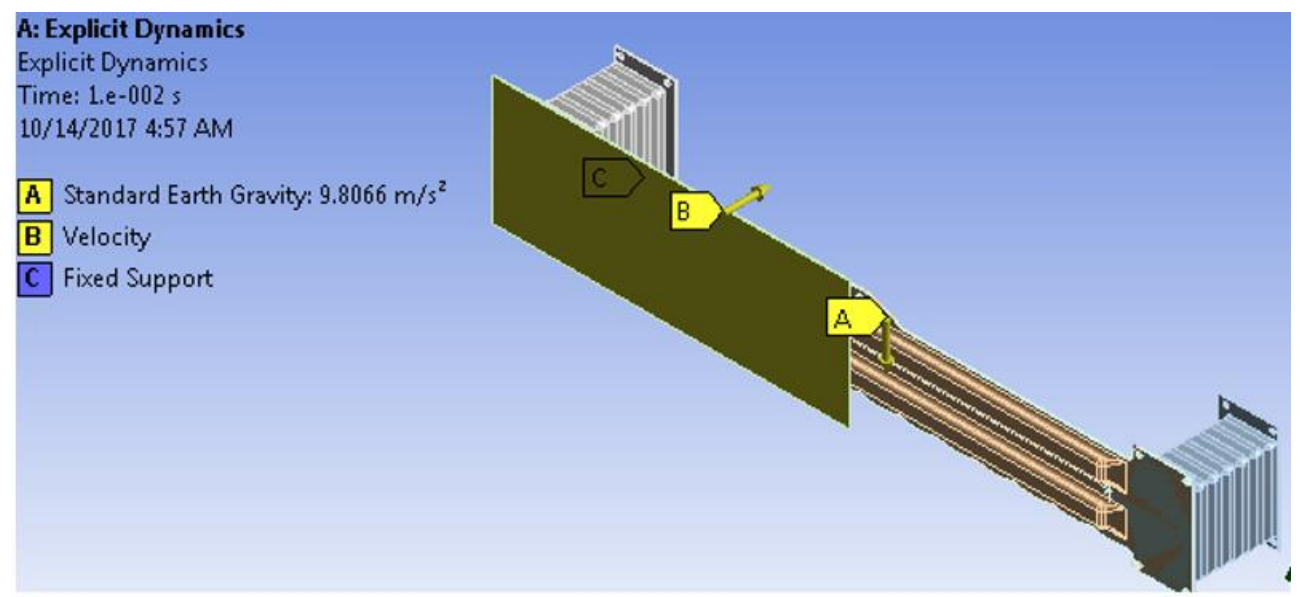

Figure 2.6 Simulation on bumper structure and crash box

\section{Result ANd Discussion}

As initial hypothesis that pre-folded can activate symmetric collapse mode (folding mechanism), it can decrease buckling mode that energy absorption is bigger and predictable and stable collapse mode resulted. It is illustrated in Figure 2.7, result of deformation after impact. In Figure 2.7(a), bumper had bigger deformation than 2.7(b) that is shown in red area. Also, there is shift between bumper and crash box in Figure 2.7(a). In Figure 2.8, time is $0,001 \mathrm{~s}$ and deformation is shown in Figure 2.8(a). It is shown in color change, which is different with Figure 2.8(b). In 0,0035 s Figure 2.8(a) had wider deformation while $2.8(\mathrm{~b})$ had upper color change. In 0,0045 s deformation is wider in $2.8(\mathrm{~b})$ yet it remains 2 stable segments. In 0,006 s Figure 2.8(a) shows the distribution of deformation in wider area in Figure 2.8(b). In 0,0085 s and 0,0095 s the origami pre-folded crash box is functioned, deformation occurs segment per segment. When upper segment unable to restrain impact, it would be transferred to the second and so forth.

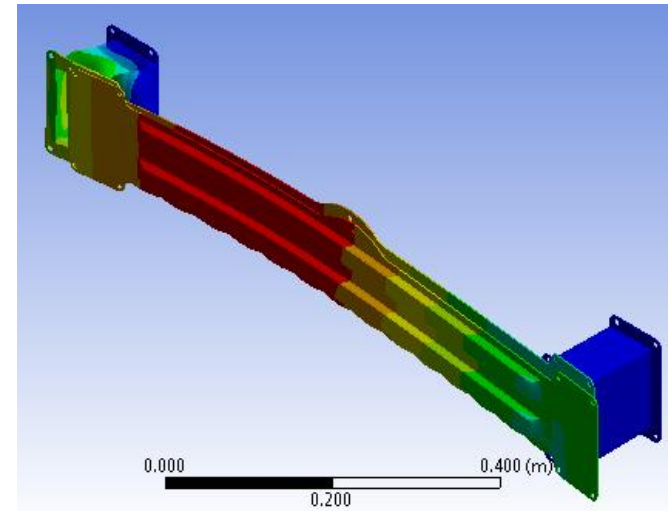

(a)

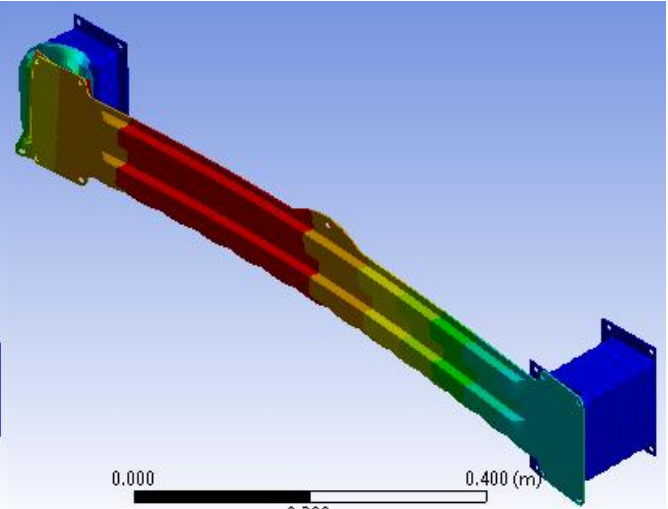

(b)

Figure 2.7 Condition of bumper structure when it is loaded, (a) rectangular crash box (b) origami crash box 


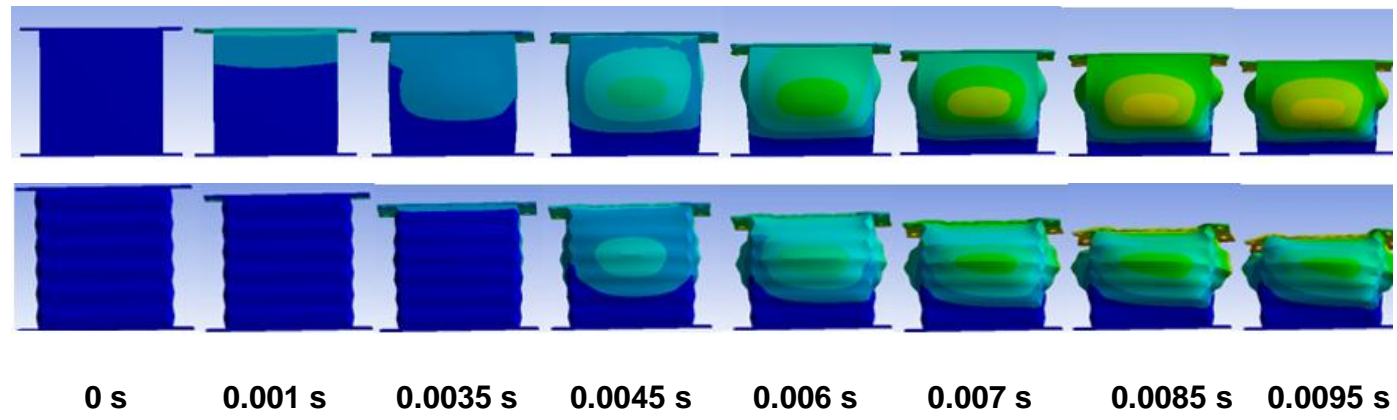

Figure 2.8 Deformation process on Crash box

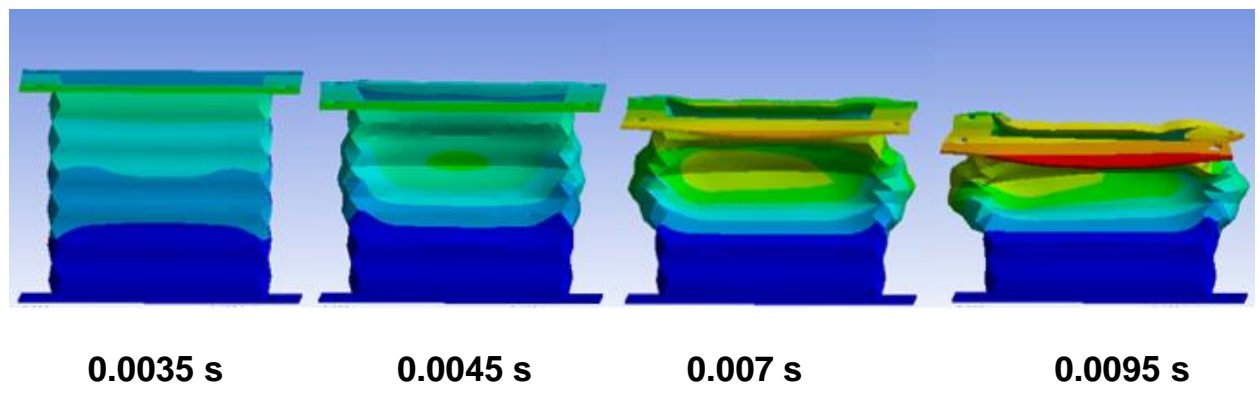

Figure 2.9 Side-section

Visually observed, Figure 2.8 and 2.10 shows buckling on rectangular and origami crash box. It caused by impact pushed crash box on the side that the buckling is convex. The phenomenon is confirmed in Figure 2.9 on other side where crash box has concave buckling. How pre-folded on origami crash box works shown in deformation process on each corners. They are designed to be open when stricken, it has impact on impact energy concentration in each segment. If a segment unable to restrain impact load, it would be transferred to lower segment. Therefore, origami crash box has two restrained segments as shown in Figure 2.9. Four upper segments has deformation. It is different with rectangular crash box that has no corner and segment that the spreading of impact energy occurs in all crash box geometry. Additional pre-folded also functioned to decrease strike on impact and has stable characteristics also able to result repetitive deformation.
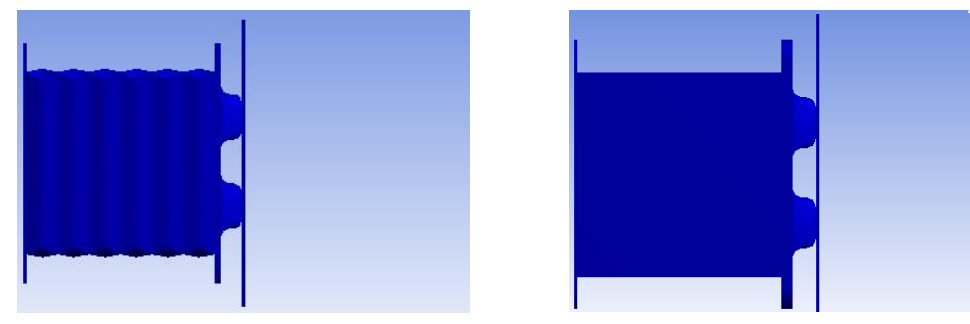

$0 \mathrm{~s}$
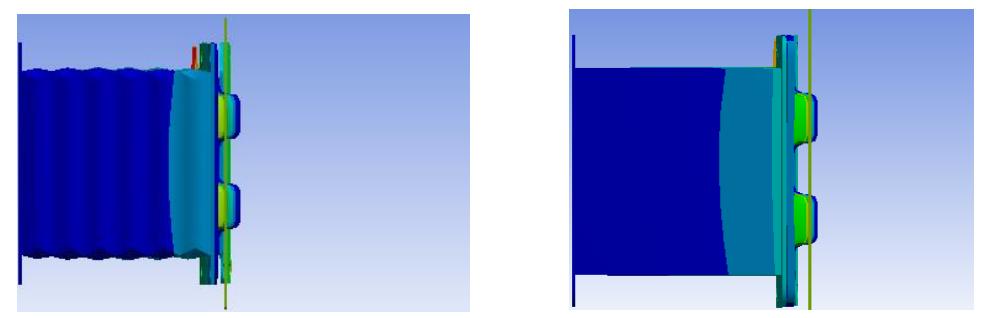

$0,001 \mathrm{~s}$

Figure 2.10 Side-section of bumper structure and crash box 

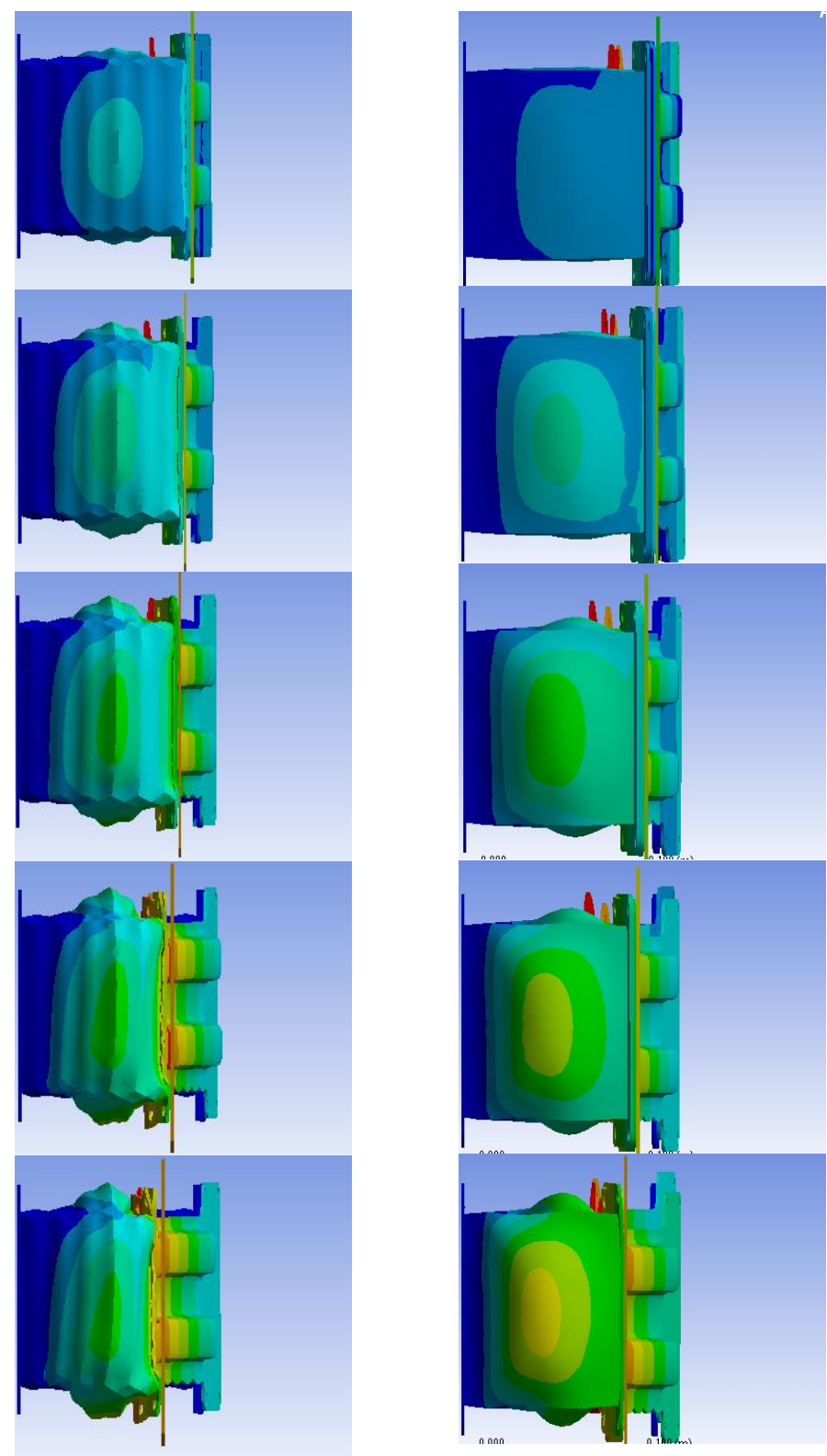

$0,0045 s$

$0,006 \mathrm{~s}$

$0.007 \mathrm{~s}$

$0.0085 \mathrm{~s}$

$0.0095 \mathrm{~s}$

Figure 2.10 Side-section of bumper structure and crash box (continued)

\section{CONCLUSiON}

From result of the research, it can be concluded that pre-folded pattern in origami crash box can muffle kinetic energy. It can be viewed from observation visual 1 origami crash box segment without plastic deformation. Pre-folded pattern in origami crash box can trigger predictable collapse mode from upper to lower. Data exposure and discussion on absorbed energy by crash box and bumper are needed in further research.

Further research conducted with the same material and variations of origami crash box adjusted to MPV size. The examination conducted per part and continued to test bumper structure in MPV. Research on full impact simulation test is needed and is expected to result energy absorption in outer and inner bumper, crash box and chassis in car structure. Research on simulation and experimental comparison also manufacture process is also needed. 
Notations:

Example in writing notation described as follow:

$\mathrm{P}_{\mathrm{m}} \quad$ : average of strike strength

$\sigma_{\mathrm{u}} \quad$ : ultimate tensile strength

$\mathrm{b}$ and $\mathrm{d}$ : column length

t : thickness

$\sigma_{0} \quad$ : material tensile

\section{REFERENCES}

[1] Bois, Paul Du, Clifford C. Chou, Bahig B. Fileta, Tawfik B. Khalil, Albert I. King, Hikmat F. Mahmood, Harold J. Mertz dan Jac Wismans (2004). Vehicle Crashworthiness And Occupant Protection. Michigan American Iron and Steel Institute 2000 Town Center Southfield, Michigan 48075.

[2] Ma, Jiayao. (2013). Energy Absorption of Thin-Walled Square Tubes With a Prefolded Origami Pattern-Part I: Geometry and Numerical Simulation. Journal of Applied Mechanics. 81. 1003-. 10.1115/1.4024405.

[3] Kusyairi, Imam, Moch. Agus Choiron dan Anindito Purnowidodo. (2015). Pengaruh Variasi Desain Crash Box Pola Origami terhadap Kemampuan Penyerapan Energi. Jurnal Rotor Universitas Negeri Jember. Vol 8 NO 2

[4] Bintarto, Redi, Andik Atmaja dan Imam Kusyairi. (2016). Analisis Penyerapan Energi Crash Box Pola Origami pada Pengujian Frontal Impact Posisi Angular Frontal. Jurnal rekayasa mesin universitas brawijaya. Vol 8 , No 1

[5] Zhou, Caihua \& Jiang, Liangliang \& Tian, Kuo \& Bi, Xiangjun \& Wang, Bo. (2017). Origami Crash Boxes Subjected to Dynamic Oblique Loading. Journal of Applied Mechanics. 84. . 10.1115/1.4037160.

[6] Zhou, Caihua \& Zhou, Yan \& Wang, Bo. (2017). Crashworthiness design for trapezoid origami crash boxes. Thin-Walled Structures. 117. 257-267. 10.1016/j.tws.2017.03.022.

[7] Filipov,E.T.,G.H. Paulino and T. Tachi. (2015). Origami tubes with reconfigurable polygonal cross-sections Proc. R.Soc.A472: 20150607.

[8] Song, Jie, Yan Chen, Guoxing Lu. (2012). Axial crushing of thin-walled structures with origami patterns. Elsevier. Thin-Walled Structures 54 (2012) 65-71

[9] Ma, Jiayao. (2011) Thin-walled Tubes with Pre-folded Origami Patterns as Energy Absorption Devices. A dissertation submitted for the degree of Doctor of Philosophy in the Department of Engineering Science at the University of Oxford

[10] Li, Siqi dkk, (2013). Origami Pattern Tube for Vehicle Crash Box, Department of Mechanical Engineering, Blekinge Institute of Technology,Karlskrona, Sweden. Bachelor of Science Thesis in Mechanical Engineering 